\title{
ANALISIS PENGARUH MODAL DAN UTANG TERHADAP PROFITABILITAS \\ (STUDI KASUS PT. MAULANA MITRA MEDIA)
}

\author{
${ }^{1}$,Ferawati, ${ }^{2}$ Pardila , ${ }^{3}$ Kasirul Fadli \\ ${ }^{1}$ Program Studi Akuntansi, Fakultas Ilmu Sosial dan Humaniora, Universitas Karimun, \\ Provinsi Kepulauan Rian, Indonesia. \\ Email : fera.universitaskarimun@gmail.com \\ ${ }^{2}$ Program Studi Akuntansi, Fakultas Ilmu Sosial dan Humaniora, Universitas Karimun, \\ Provinsi Kepulauan Riau, Indonesia \\ Email : pardila22@gmail.com \\ ${ }^{3}$ Program Studi Akuntansi, Fakultas Ilmu Sosial dan Humaniora, Universitas Karimun, \\ Provinsi Kepulauan Riau, Indonesia \\ Email : khasirulfadli@gmail.com
}

\begin{abstract}
Abstrak
Tujuan dari penelitian ini adalah untuk mengetahui apakah terdapat pengaruh Modal dan Utang terhadap profitabilitas di PT. Maulana Mitra Media secara parsial dan simultan. Dalam penelitian ini digunakan sebanyak 36 sampel penelitian dalam rentang waktu 3 tahun (2016-2018). Teknik analisis data yang digunakan dalam penelitian ini menggunakan metode positifisme. Metode analisis yang digunakan adalah model analisis regresi linear berganda yang dilakukan dengan bantuan program komputer SPSS versi 25 for windows.

Hasil uji t menunjukkan bahwa modal berpengaruh terhadap profitabilitas hal ini dibuktikan dengan nilai t hitung sebesar 5,728 lebih besar dari t tabel 1,688 dan signifikan sebesar $0,00<$ dari tingkat yang diisyaratkan yaitu 0,05 . Hasil uji utang tidak berpengaruh terhadap profitabilitas hal ini dibuktikan dengan nilai $t$ hitung sebesar 3,207 lebih kecil dari t tabel sebesar 1,688 dan signifikan 0,003 < dari tingkat signifikan yang diisyaratkan yaitu 0,05 . Secara simultan modal dan Utangsecara simultan berpengaruh terhadap profitabilitas hal ini dibuktikan dengan $\mathrm{F}$ hitung sebesar 17.097 lebih besar dari $\mathrm{F}$ tabel sebesar 3,259 dan signifikan sebesar $0,00<$ dari tingkat signifikasi yang diisyaratkan yaitu 0,005
\end{abstract}

\section{Kata Kunci : Modal, Utang dan Profitabilitas}

\section{PENDAHULUAN}

Perkembangan suatu perusahaan dititikberatkan pada bagaimana cara perusahaan tersebut mencapai tujuan utamanya, yaitu tercapainya profitabilitas perusahaan. Besar kecilnya profit yang diperoleh perusahaan merupakan ukuran keberhasilan perusahaan dalam mengelola operasional perusahaannya dan profit yang digunakan oleh manajemen dalam mengambil keputusan. Salah satu keputusan yang dapat diambil oleh 
perusahaan dalam mencapai tujuannya untuk memaksimalkan laba adalah keputusan modal.

Modal merupakan suatu tindakan dimana perusahaan memanfaatkan utang sebagai sumber dana untuk mencapai profit perusahaan yang optimum. utang merupakan salah satu sumber modal atau dana perusahaan guna membiayai perusahaan agar dapat terus mengembangkan usahanya dan membantu perusahaan dalam mencapai tujuannya yaitu memaksimalkan kekayaan pemilik melalui maksimalisasi profitabilitas.

Utang biasanya digunakan untuk memenuhi kebutuhan modal perusahaan dalam menghadapi masa operasional yang tinggi, seperti kebutuhan untuk aktiva lancar. Perusahaan dengan modal yang cukup besar harus melakukan ekspansi dan memerlukan waktu yang cukup lama pula untuk modal dari ekspansi. Selain itu perusahaan lebih memilih menggunakan adanyautang sebagai sumber dana dikarena pada umumnya bunga yang dibayarkan oleh perusahaan. Karena menggunakan utang merupakan suatu manfaat yang menguntungkan bagi perusahaan yang dapat digunakan untuk mengurangi pajak penghasilan. Secara sederhana, ini adalah cara mengkaji bagaimana sebuah perusahaan menggunakan berbagai sumber dana berbeda untuk mendanai biaya operasional.

Tabel 1.1 Data Modal Pada PT. Maulana Mitra Media

Periode $2016-2018$

\begin{tabular}{|c|c|c|c|c|}
\hline \multirow{2}{*}{ No } & \multirow{2}{*}{ Bulan } & \multicolumn{3}{|c|}{ Tahun } \\
\cline { 3 - 5 } & & $\mathbf{2 0 1 6}$ & $\mathbf{2 0 1 7}$ & $\mathbf{2 0 1 8}$ \\
\hline 1 & Januari & $100,000,000$ & $340,000,000$ & $398,045,000$ \\
\hline 2 & Februari & $100,000,000$ & $343,050,000$ & $384,000,000$ \\
\hline 3 & Maret & $105,000,000$ & $250,000,000$ & $377,056,200$ \\
\hline 4 & April & $210,000,000$ & $345,000,000$ & $389,000,000$ \\
\hline 5 & Mei & $373,107,682$ & $100,000,000$ & $375,000,000$ \\
\hline 6 & Juni & $325,000,000$ & $253,040,000$ & $300,000,000$ \\
\hline 7 & Juli & $335,067,828$ & $254,860,000$ & $401,050,666$ \\
\hline 8 & Agustus & $365,872,225$ & $304,050,333$ & $390,700,000$ \\
\hline 9 & September & $372,575,682$ & $340,000,000$ & $355,000,000$ \\
\hline 10 & Oktober & $370,000,580$ & $347,500,000$ & $363,050,000$ \\
\hline 11 & November & $407,540,235$ & $390,000,605$ & $399,000,000$ \\
\hline 12 & Desember & $410,381,437$ & $396,005,000$ & $405,030,000$ \\
\hline & Total & $3,474,545,669$ & $3,663,505,938$ & $4,536,931,866$ \\
\hline
\end{tabular}

Sumber : Data Internal PT. Maulana Mitra Media

Tabel 1.2 Data Utang Pada PT. Maulana Mitra Media

Periode $2016-2018$

\section{No $\quad$ Bulan}

Tahun 


\begin{tabular}{|r|c|r|r|r|}
\hline & & $\mathbf{2 0 1 6}$ & \multicolumn{1}{c|}{$\mathbf{2 0 1 7}$} & \multicolumn{1}{c|}{$\mathbf{2 0 1 8}$} \\
\hline 1 & Januari & $15,070,000$ & $150,700,000$ & $10,000,000$ \\
\hline 2 & Februari & $17,050,000$ & $103,000,000$ & $38,900,000$ \\
\hline 3 & Maret & $17,065,000$ & $93,005,000$ & $167,000,000$ \\
\hline 4 & April & $60,570,000$ & $95,000,000$ & $85,800,000$ \\
\hline 5 & Mei & $76,050,000$ & $90,400,000$ & $74,000,000$ \\
\hline 6 & Juni & $205,000,000$ & $56,000,500$ & $102,900,000$ \\
\hline 7 & Juli & $97,000,000$ & $72,000,000$ & $79,600,000$ \\
\hline 8 & Agustus & $155,000,000$ & $110,050,000$ & $67,025,000$ \\
\hline 9 & September & $89,050,000$ & $110,970,000$ & $78,900,000$ \\
\hline 10 & Oktober & $79,066,000$ & $90,009,000$ & $81,030,000$ \\
\hline 11 & November & $120,000,000$ & $57,000,000$ & $77,008,000$ \\
\hline 12 & Desember & $92,990,000$ & $62,000,500$ & $138,000,000$ \\
\hline & Total & $1,023,911,000$ & $1,090,135,000$ & $1,000,163,000$ \\
\hline
\end{tabular}

Sumber : Data Keuangan PT. Maulana Mitra Media

Tabel 1.3 Data Profitabilitas Pada PT. Maulana Mitra Media

Periode $2016-2018$

\begin{tabular}{|c|c|c|c|c|}
\hline \multirow{2}{*}{ No } & \multirow{2}{*}{ Bulan } & \multicolumn{3}{|c|}{ Tahun } \\
\cline { 3 - 5 } & & $\mathbf{2 0 1 6}$ & $\mathbf{2 0 1 7}$ & $\mathbf{2 0 1 8}$ \\
\hline 1 & Januari & $84,930,000$ & $189,300,000$ & $388,045,000$ \\
\hline 2 & Februari & $233,002,500$ & $240,050,000$ & $345,100,000$ \\
\hline 3 & Maret & $348,435,000$ & $156,995,000$ & $210,056,200$ \\
\hline 4 & April & $239,437,500$ & $250,000,000$ & $303,200,000$ \\
\hline 5 & Mei & $201,000,000$ & $20,590,000$ & $301,000,000$ \\
\hline 6 & Juni & $307,133,245$ & $197,039,500$ & $299,000,000$ \\
\hline 7 & Juli & $238,067,828$ & $182,860,000$ & $321,450,666$ \\
\hline 8 & Agustus & $210,872,225$ & $194,000,333$ & $323,675,000$ \\
\hline 9 & September & $283,525,682$ & $229,030,000$ & $276,100,000$ \\
\hline 10 & Oktober & $290,934,580$ & $257,491,000$ & $282,020,000$ \\
\hline 11 & November & $323,540,235$ & $333,000,605$ & $321,992,000$ \\
\hline 12 & Desember & $317,391,437$ & $334,004,500$ & $267,030,000$ \\
\hline & Total & $3,078,270,232$ & $2,584,360,938$ & $3,638,668,866$ \\
\hline
\end{tabular}

Sumber : Data Keuangan PT. Maulana Mitra Media

Statemen keuangan di PT. Maulana Mitra Media berpengaruh besar terhadap kesejahteraan perusahaan, dimana permasalahan di perusahaan ini utang nya sering tidak kondusif pada periode tertentu.Utang yang terus berjalan di setiap periode tidak lepas dari aktiva lancar dengan jumlah yang tak terduga bahkan tidak sesuai dengan 
modal internal perusahaan ini. Sedang kan profitabilittas terus mengikuti gerakan alur modal dan utang, apabila tidak terkontrol maka bisa menyebabkan perusahaan ini bangkrut.

Berdasarkan latar belakang tersebut bahwa pentingnya penggunaan modal dan utang perusahaan yang dapat mempengaruhi profit perusahaan, maka penulis tertarik untuk melakukan penelitian yang berjudul "Analisis Pengaruh Modal dan Utang Terhadap Profitabilitas (Studi Kasus PT. Maulana Mitra Media).

\subsection{Modal}

\section{TINJAUAN PUSTAKA}

Menurut Brigham (2006:62) menyatakan bahwa "Modal atau modal adalah jumlah dari utang jangka panjang, saham preferen, dan ekuitas saham biasa, atau mungkin juga dari pos-pos tersebut dengan plus utang jangka pendek yang dikenakan bunga. Menurut Riyano (2001:17) bahwa pengertian modal adalah hasil produksi yang digunakan untuk memproduksi lebih lanjut. Dalam perkembannya berubah yang bersifat non physical oriented yaitu lebih ditekankan kepada nilai daya beli, kekuasaan memakai atau menggunakan hal yang terkandung dalam barang-barang modal. Menurut Standar Akuntansi Keuangan (IAI, 2007:9) bahwa pengertian modal adalah hak residual atau asset perusahaan setelah dikurangi semua kewajiban.

Sehingga dapat disimpulkan bahwa pengertian modal atau ekuitas pemegang saham adalah jumlah total dari dua sumber utama ekuitas saham, yaitu modal disetor dan laba ditahan setelah dikurangi semua kewajiban sebagai kekuasaan untuk menggunakan barang-barang modal.

\section{Faktor Yang Mempengaruhi Struktur Modal}

Struktur modal yang optimal adalah struktur modal yang dapat meminimalkan biaya penggunaan modal keseluruhan atau biaya modal rata-rata sehingga akan memaksimalkan nilai perusahaan. Terdapat empat faktor yang mempengaruhi struktur modal, yaitu sebagai berikut (Brigham dan Houston, 2001:6):

1. Risiko bisnis. Tingkat risiko yang terkandung dalam operasi perusahaan apabila ia tidak menggunakan utang. Makin besar risiko bisnis perusahaan, makin rendah rasio utang yang optimal.

2. Posisi pajak perusahaan. Alasan utama menggunakan utang adalah karena biaya bunga dapat dikurangkan dalam perhitungan pajak, sehingga menurunkan biaya utang yang sesungguhnya.

3. Fleksibilitas keuangan. Kemampuan untuk menambah modal dengan persyaratan yang wajar dalam keadaan yang memburuk. Para manajer dana perusahaan mengetahui bahwa penyedia modal yang mantap diperlukan untuk operasi yang stabil, yang merupakan faktor yang sangat menentukan keberhasilan jangka panjang. 
4. Konservatisme atau agresivitas manajemen. Sebagian manajemen lebih agresif dari yang lain, sehingga sebagian perusahaan lebih cenderung menggunakan utang untuk meningkatkan laba. Faktor ini tidak mempengaruhi struktur modal yang optimal atau yang memaksimalkan nilai, tetapi akan mempengaruhi struktur modal yang ditargetkan yang ditetapkan manajer.

\subsection{Utang}

Menurut Kasmir, (2008:40) Utang Lancar merupakan kewajiban atau utang perusahaan pada pihak lain yang harus segera dibayar, jangka waktu utang lancar adalah satu tahun. Mamduh M. Hanafi (2010;29) mendefiniskan“"Hutang sebagai pengorbanan ekonomis yang mungkin timbul dimasa mendatang dari kewajiban organisasi sekarang untuk mentransfer asset atau memberikan jasa ke pihak lain dimasa mendatang, sebagai akibat transaksi atau kejadian dimasa lalu. Hutang muncul terutama karena penundaan pembayaran untuk barang atau jasa yang telah diterima oleh organisasi dan dari dana yang dipinjam".

Menurut S. Munawir $(2007 ; 18)$ Hutang lancar atau hutang jangka pendek adalah kewajiban keuangan perusahaan yang pelunasan atau pembayaran akan dilakukan dalam jangka waktu pendek (satu tahun sejak tanggal neraca) dengan menggunakan aktiva lancar yang dimiliki oleh perusahaan.

Sehingga dapat disimpulkan bahwa utang adalah kewajiban perusahaan pada pihak lain yang harus segera dibayar dalam jangka waktu tertentu sebagai pengorbanan ekonomis perusahaan pada masa sekarang dan masa depan atas barang atau jasa yang telah diterima dengan pelunasan menggunakan aktiva lancar yang dimiliki oleh perusahaan.

\section{Karakteristik Utang}

Adapun karakteristik dari hutang adalah sebagai berikut:

1. Merupakan kewajiban yang berasal dari transaksi masa lalu.

2. Dapat diukur dan dinyatakan dalam satuan mata uang yang diterima umum.

3. Memiliki nominal yang pasti dan dapat ditaksir jumlahnya.

4. Menyertakan aktiva atau aset yang dapat diterima di masa mendatang.

5. Diketahui dengan jelas pihak yang meminjam dan memberi pinjaman.

6. Diketahui dengan jelas tanggal jatuh tempo.

7. Tidak dapat membatalkan atau melepaskan diri dari kewajiban.

\subsection{Profitabilitas}

Menurut G. Sugiyarso dan F.Winarni (2005:118) menyatakan bahwa "Profitabilitas adalah kemampuan perusahaan memperoleh laba dalam hubungan dengan penjualan total aktiva maupun modal sendiri". Dari definisi ini terlihat jelas bahwa sasaran yang akan dicari adalah laba perusahaan.

Menurut Harahap (2009:304) menyatakan bahwa "Rasio rentabilitas atau disebut juga profitabilitas menggambarkan kemampuan perusahaan mendapatkan laba melalui 
semua kemampuan, dan sumber yang ada seperti kegiatan penjualan, Skas, modal, jumlah karyawan, jumlah cabang, dan sebagainya”. Rasio yang menggambarkan kemampuan perusahaan menghasilkan laba disebut juga operating ratio. Sedangkan menurut Kasmir (2013:196) mengatakan bahwa Rasio Profitabilitas merupakan rasio untuk menilai kemampuan perusahaan dalam mencari keuntungan.

Dapat disimpulkan profitabilitas merupakan gambaran kinerja fundamental perusahaan ditinjau dari tingkat efisiensi dan efektivitas operasi perusahaan dalam memperoleh laba. Hal ini ditunjukkan dengan laba yang dihasilkan dari penjualan dan pendapatan investasi.Intinya bahwa penggunaan rasio ini menunjukkan efesiensi perusahaan.mengapa rasio profitabilitas sangat penting bagi perusahaan dikarenakan untuk dapat melangsungkan hidupnya, suatu perusahaan harus berada dalam keadaan yang menguntungkan (profitable).

Tanpa adanya keuntungan (profit), maka akan sangat sulit bagi perusahaan untuk menarik modal dari luar. Para kreditur, pemilik perusahaan, dan terutama pihak manajemen perusahaan akan berusaha meningkatkan keuntungan karena disadari benar betapa pentingnya arti dari profit terhadap kelangsungan dan masa depan perusahaan. Profitabilitas suatu perusahaan menunjukkan perbandingan antara laba dengan aktiva atau modal yang menghasilkan laba tersebut. Dengan kata lain, profitabilitas adalah kemampuan suatu perusahaan untuk mencapai laba.

\section{Usaha Meningkatkan Profitabilitas Ekonomi}

Profitabilitas ekonomi atau earning power mempunyai arti yang penting bagi perusahaan, maka perlu diusahakan agar tingkat profitabilitas meningkat. Faktor-faktor yang mempengaruhi profitabilitas Menurut Bambang Riyanto (1997:37) tinggi rendahnya earning power dipengaruhi oleh:

1. Profit margin, yaitu perbandingan antara net operating income atau laba bersih usaha dibandingkan dengan net sales atau penjualan bersih dan dinyatakan dalam presentase $(\%)$ yang dapat dirumuskan sebagai berikut:

\section{(Laba Usaha / Penjualan Bersih) x 100\%}

2. Turner of operating asset, yaitu dengan jalan membandingkan antara net sales atau penjualan bersih dengan operating asset atau modal usaha yang di rumuskan dengan:

Penjualan bersih / Modal usaha

Usaha untuk memperbesar profitabilitas merupakan harapan bagi manajer perusahaan, oleh karena itu untuk mempertinggi profitabilitas perlu diketahui berbagai faktor-faktor yang menentukan tinggi rendahnya profitabilitas ekonomi. Cara untuk meningkatkan profitabilitas ekonomi menurut Bambang Riyanto (1997) :

1. Menaikkan profit margin dengan menambah biaya usaha sampai tingkat tertentu diusahakan tercapainya tambahan sales yang lebih besar daripada tambahan operating expense. Juga dengan mengurangi pendapatan dari sales sampai tingkat 
tertentu atau mengurangi usaha relatif lebih besar dari berkurangnya pendapatan dari sales.

2. Menaikkan atau mempertinggi turnorver of operating asset Dengan menambah modal usaha dan juga dengan mengurangi sales sampai tingkat tertentu diusahakan penurunan operating asset sebesar-besarnya.

\section{METODE PENELITIAN}

\subsection{Desain Penelitian}

Penelitian ini bersifat deskriptif analitis dengan desain studi kasus dalam proses pemecahan masalah tersebut. Untuk menunjang keberhasilan penelitian, penulis mengumpulkan data yang aktual mengenai permasalahan di atas dengan melaksanakan teknik studi dokumentasi.

Metode yang digunakan dalam penelitian ini adalah metode kuantitatif karena data penelitian berupa angka-angka dan analisis menggunakan statistik.Metode ini bertujuan untuk mengungkap masalah-masalah dengan mengumpulkan data, menyusun, mengklarifikasikan, menganalisa, serta menginterprestasikan data berupa angka atau skor.

\subsection{Objek Penelitian}

Adapun objek penelitian dalam tulisan ini adalah laporan keuangan PT. Maulana Mitra Media meliputi modal dan utang serta profitabilitas di PT. Maulana Mitra Media.

\subsection{Identifikasi Variabel}

Adapun variabel - variabel yang digunakan dalam penelitian ini dapat dibagi menjadi dua macam yaitu variabel independen atau variabel bebas (X) adalah modal $\left(\mathrm{X}_{1}\right)$ dan utang $\left(\mathrm{X}_{2}\right)$ serta variable dependen atau terikat yang akan diteliti adalah profitabilitas di PT. Maulana Mitra Media.

\subsection{Definisi Operasional Variabel}

Berdasarkan identifikasi variabel di atas, maka definisi operasional variabel dalam penelitian ini adalah sebagai berikut:

1. Modal $\left(\mathrm{X}_{1}\right)$, yaitu sekumpulan uang atau barang yang digunakan sebagai dasar untuk melaksanakan suatu pekerjaan. Dalam bahasa Inggris modal disebut dengan modal, yaitu barang yang dihasilkan oleh alam atau manusia untuk membantu memproduksi barang lainnya yang dibutuhkan manusia dengan tujuan untuk memperoleh keuntungan.

2. Utang $\left(\mathrm{X}_{2}\right)$, yaitu kewajiban keuangan perusahaan yang pelunasan atau pembayaran akan dilakukan dalam jangka waktu pendek (satu tahun sejak tanggal neraca) dengan menggunakan aktiva lancar yang dimiliki oleh perusahaan. 
3. Profitabilitas (Y), yaitu suatu ukuran dalam persentase yang digunakan untuk menilai sejauh mana perusahaan mampu menghasilkan laba pada tingkat yang dapat diterima. Angka profitabilitas dinyatakan antara lain dalam angka laba sebelum atau sesudah pajak, laba investasi, pendapatan persaham, dan laba penjualan. Nilai profitabilitas menjadi norma ukuran bagi kesehatan perusahaan.

\subsection{Populasi dan Sampel}

Populasi dalam penelitian ini adalah data laporan keuangan internal pada PT. Maulana Mitra Media. Sampel dalam penelitian ini adalah sebagian dari jumlah populasi data laporan di PT. Maulana Mitra Media. Dan teknik pengambilan sampel menggunakan nonprobability sampling, yaitu suatu metode pemilihan sampel, dimana setiap anggota populasi mempunyai peluang yang sama untuk dipilih menjadi anggota sampel (Husein Umar,2019:59).

\subsection{Jenis dan Sumber Data}

Jenis data yang digunakan dalam penelitian ini adalah data kuantitatif dengan pendekatan asosiatif guna menganalisia pengaruh modal dan utang terhadap proftabilitas di PT. Maulana Mitra Media.

Sumber data skunder yang mengacu pada informasi yang dikumpulkan dari sumber yang telah ada di PT. Maulana Mitra Media.

\subsection{Teknik Pengumpulan Data}

Teknik pengumpulan data yang digunakan dalam penelitian ini adalah melalui:

a. Observasi

Metode pengumpulan data dengan pengamatan dan pencatatan secara sistematik terhadap gejala yang tampak pada objek penelitian (Husein Umar,2019:94).

b. Dokumentasi

Teknik dokumentasi ini digunakan dalam pengumpulan data dengan melihat catatancatatan atas data jumlah modal kerja serta biaya produksi yang berhubungan dengan penelitian ini.

\subsection{Metode Analisis Data}

Adapun analisis data dalam penelitian ini menggunakan Regresi Linier Berganda.Sedangkan untuk pengolahan data menggunakan perangkat lunak (Software) statistik SPSS (Statistical Product and Service Solutions) versi 25. Data - data tersebut dianalisis dengan menggunakan tahapan uji asumsi klasik (uji normalitas, uji multikolinearitas, uji heteroskedasitas, dan uji autokorelasi) dan hipotesis (uji t, uji F, dan uji adjusted $R$ square).

\section{HASIL DAN PEMBAHASAN}




\section{Hasil Uji Normalitas}

Pengujian normalitas dengan metode analisis grafik normal probability plot, tujuan nya untuk menguji normalitas, dari model regresi penelitian ini daapat dilihat pada gambar dibawah ini :

\section{Gambar 4.1}

Grafik Normal Probability Plot

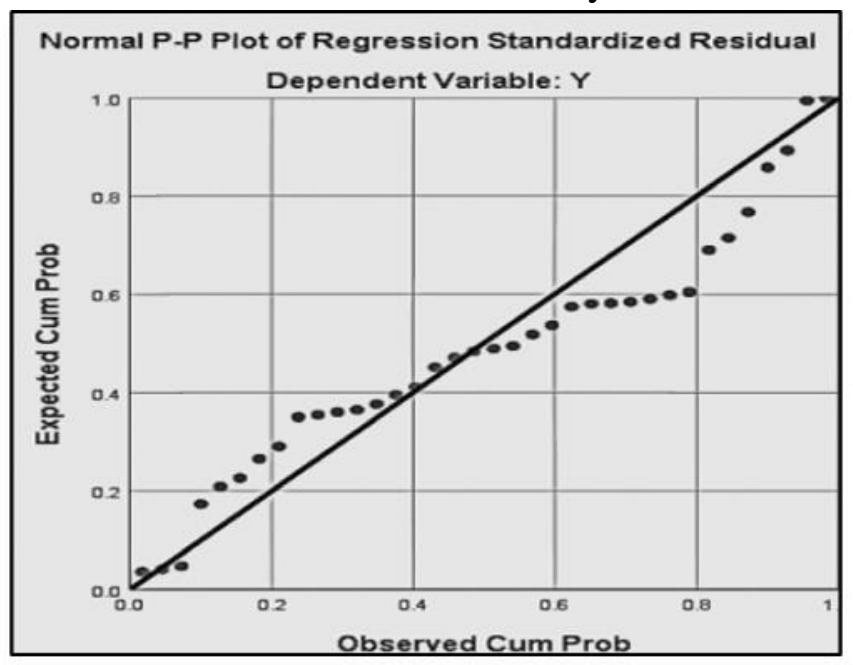

Sumber : Data Olahan (2019)

Berdasarkan gambar diatas terlihat grafik plot, dimana terlihat titik - titik menyebar dan mengikuti garis diagonalnya, sehingga dapat disimpulkan bahwa model regresi memenuhi syarat normalitas.

\section{Hasil Uji Multikolinearitas}

Hasil Uji multikolinearitas dapat dilihat pada tabel dibawah ini :

Tabel 4.2 Hasil Uji Multikolinearitas

\begin{tabular}{|l|r|r|l|}
\hline & \multicolumn{2}{|c|}{ Collinearity Statistics } & \\
Model & Tolerance & VIF & Kesimpulan \\
\hline 1 (Constant) & .864 & 1.158 & Tidak Terjadi Multikolinearitas \\
Modal & .864 & 1.158 & Tidak Terjadi Multikolinearitas \\
\hline Utang & & & \\
\hline
\end{tabular}

Sumber : Data Olahan (2019)

Dari tabel 4.2 menunjukkan bahwa tidak ada variabel yang memiliki Variance Inflation Factor (VIF) < 10 dan Tolerance Value > dari 0,10 dalam pengujian model regresi. Dari data tersebut dapat disimpulkan bahwa tidak ada multikolinearitas antar variabel independen yang digunakan dalam model regresi.

\section{Hasil Uji Autokorelasi}


Hasil uji autokorelasi dapat dilihat pada tabel dibawah ini :

Tabel 4.3 Hasil Uji Autokorelasi

Model Sumarryb

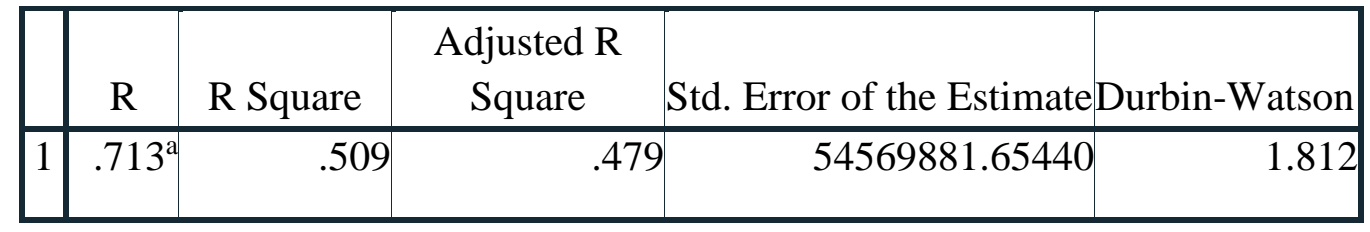

a. Predictors: (Constant), modal, utang

b. Dependent Variabel: Profitabilitas

Sumber : Data Olahan (2019)

Dari hasil output diatas didapat nilai DW yang dihasilkan dari model regresi adalah 1,812 maka tidak terjadi autokorelasi.

\section{Hasil Uji Heteroskedastisitas}

Hasil pengujian heteroskedastisitas dapat dilihat pada gambar berikut :

Gambar 4.2 Hasil Uji Heteroskedastisitas

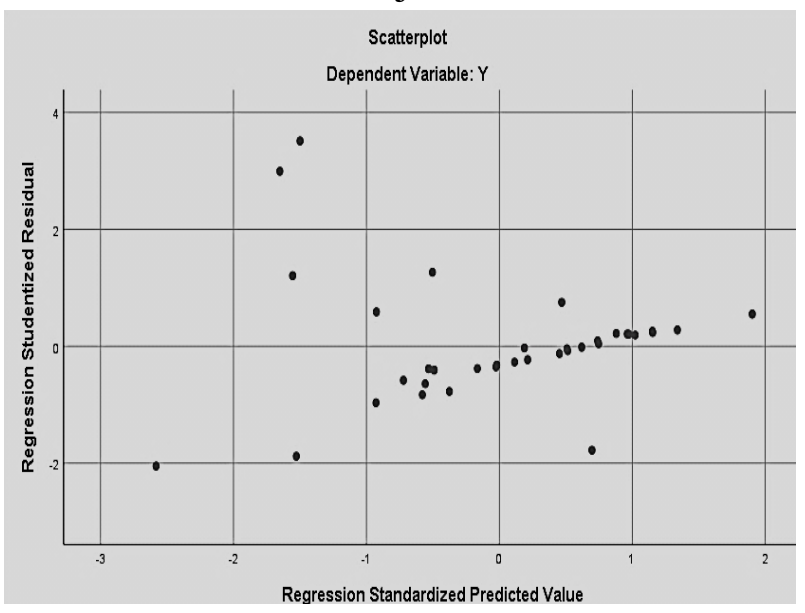

Sumber:Data Olahan (2019)

Dari grafik scatterplot terlihat bahwa titik-titik menyebar secara acak dan tidak membentuk suatu pola tertentu serta tersebar di ata maupun dibawah angka nol pada sumbu Y, sehingga dapat disimpulkan bahwa tidak terjadi heteroskedastisitas pada model regresi, sehingga model regresi layak dipakai untuk memprediksi berdasarkan masukan variabel independennya.

\subsection{Hasil Regresi Linier Berganda}

Berdasarkan perhitungan SPSS 25 diperoleh persamaan regresi linier berganda sebagaimana yang tersaji pada tabel 4.4 sebagai berikut :

Tabel 4.4 Regresi Linier Berganda SPSS

\section{Cooficients $^{\mathrm{a}}$}




\begin{tabular}{|c|c|c|c|c|c|}
\hline \multirow[b]{2}{*}{ Model } & \multicolumn{2}{|c|}{ Unstandardized Coefficients } & \multirow{2}{*}{\begin{tabular}{|c|}
$\begin{array}{c}\text { Standardized } \\
\text { Coefficients }\end{array}$ \\
Beta \\
\end{tabular}} & \multirow[b]{2}{*}{$t$} & \multirow[b]{2}{*}{ Sig. } \\
\hline & B & Std. Error & & & \\
\hline 1 (Constant) & 126558829.367 & 34124756.310 & & 3.709 & .001 \\
\hline Modal & .608 & .106 & .752 & 5.728 & .000 \\
\hline Utang & -.755 & .235 & -.421 & -3.207 & .003 \\
\hline
\end{tabular}

a. Dependent Variable : Profitabilitas

Sumber : Data Olahan (2019)

Berdasarkan Tabel 4.4 maka persamaannya dapat dimasukkan ke dalam persamaan regresi berganda sebagai berikut :

$$
\begin{aligned}
& \qquad \mathrm{Y}=\mathrm{a}+\mathrm{b} 1 . \mathrm{X} 1+\mathrm{b} 2 . \mathrm{X} 2 \\
& \mathrm{Y}=126558829.367+0.608 \mathrm{X} 1+-0.755 \mathrm{X} 2 \\
& \text { Keterangan : } \\
& \mathrm{Y}=\text { Profitabilitas } \\
& \mathrm{X} 1=\text { Modal } \\
& \mathrm{X} 2=\text { Utang } \\
& \mathrm{a} \quad=\text { Konstant }
\end{aligned}
$$

Dapat disimpulkan dari perhitungan SPSS pada Tabel 4.4 bahwa variabel modal (X1) diperoleh nilai t hitung sebesar 5,728 lebih besar daripada t Tabel sebesar 1,688 dan dengan tingkat sig 0.00 yang berarti nilai sig $<(\alpha) 0.05$ atau dengan taraf signifikansi kurang dari 0.05 maka H0 berhasil ditolak, dengan demikian hipotesis yang menyatakan modal berpengaruh signifikan terhadap profitabilitas pada PT. Maulana Mitra Media terbukti benar. Dari hasil penelitian pada variabel utang (X2) diperoleh nilai t hitung sebesar -3,207 lebih kecil daripada t Tabel sebesar 1,688 dan dengan tingkat sig 0.003 yang berarti nilai sig $>(\alpha) 0.05$ atau dengan taraf signifikansi lebih dari 0.05 maka H0 diterima, dengan demikian hipotesis yang menyatakan utang berpengaruh signifikan terhadap profitabilitas pada PT. Maulana Mitra Media terbukti salah.

Salah satu faktor yang mempengaruhi besarnya profitabilitas adalah kondisi peredaran modal pada perusahaan itu sendiri. Semakin tinggi tingkat peredara modal maka semakin besar pula profitabilitas usaha yang akan diperoleh oleh perusahaan tersebut. Dan solusi untuk menaikkan profitabilitas tersebut adalah melakukan perluasan modal dari modal eksternal yang berasal dari luar perusahaan atau dana yang diperoleh dari para kreditur, dengan demikian tingkat modal akan memajukan perusahaan.

\subsection{Hasil Uji Hipotesis Statistik F (Simultan)}


Uji F yang dilakukan untuk melihat besarnya pengaruh dan tingkat signifikan antara variabel independen secara simultan terhadap variabel ini menggunakan SPSS 25 disajikan pada tabel 4.7 sebagai berikut :

Tabel 4.7 Hasil Uji F Menggunakan SPSS

ANOVA $^{\mathrm{a}}$

\begin{tabular}{|c|c|c|c|c|c|}
\hline Model & Sum of Squares & Df & Mean Square & $\mathrm{F}$ & Sig. \\
\hline \multirow[t]{2}{*}{1 Regression } & & 2 & & 17.097 & $.000^{\mathrm{b}}$ \\
\hline & $1.01828 \mathrm{E}+17$ & & 5.09139E+16 & & \\
\hline Residual & $982698 \mathrm{E}+16$ & 33 & & & \\
\hline \multirow[t]{2}{*}{ Total } & & 35 & & & \\
\hline & $2.00098 \mathrm{E}+17$ & & & & \\
\hline
\end{tabular}

a. Dependent Variable: Profitabilitas

b. Predictors: (Constant), Modal, Utang

Sumber : Data Olahan (2019)

Berdasarkan hasil perhitungan SPSS uji F, nilai $\mathrm{F}$ hitung yang diperoleh adalah sebesar 17,097 lebih besar daripada F Tabel sebesar3,259 dan dengan tingkat sig 0.00 yang berarti nilai sig $<(\alpha) 0.05$ maka dapat disimpulkan bahwa seluruh variabel independen secara simultan memiliki pengaruh yang signifikan terhadap variabel dependen.

Maka demikian $\mathrm{H} 0$ ditolak dan Ha diterima yaitu terdapat pengaruh signifikan perputaran modal dan utang terhadap profitabilitas. Hasil penelitian membuktikan bahwa model regresi dalam penelitian ini dapat digunakan untuk memprediksi faktor yang mempengaruhi profitabilitas perusahaan.

\subsection{Hasil Koefisien Determinasi}

Hasil uji koefisien determinasi (R2) dengan menggunakan perhitungan SPSS 25 dari persamaan regresi disajikan pada tabel 4.10 dibawah ini :

Tabel 4.10 Hasil Koefisien Determinasi SPSS

Model Sumarryb

\begin{tabular}{|l|r|r|r|r|}
\hline & $\mathrm{R}$ & R Square & $\begin{array}{c}\text { Adjusted R } \\
\text { Square }\end{array}$ & Std. Error of the Estimate \\
\hline 1 & $.713^{\mathrm{a}}$ & .509 & .479 & 54569881.65440 \\
\hline
\end{tabular}

Sumber : Data Olahan (2019)

Berdasarkan tabel 4.10 dan dari perhitungan manual dapat diketahui nilai koefisien determinasi (R2) sebesar 0,509 atau 50,9\%.Artinya variabel modal dan utang berpengaruh terhadap variabel profitabilitas sebesar 50,9\%, sedangkan sisanya 49,1\% dijelaskan oleh variabel lain yang tidak dimasukkan dalam model regresi ini. Hal ini 
menunjukkan bahwa masih ada variabel lain di luar variabel modal dan utang yang berpengaruh terhadap profitabilitas.

\section{KESIMPULAN}

\section{Kesimpulan}

Penelitian ini bertujuan untuk mengetahui pengaruh antar modal dan utang terhadap profitabilitas pada PT. Maulana Mitra Media. Berdasarkan hasil analisis, maka kesimpulan yang dapat diambil dari penelitian ini sebagai berikut :

1 .

Modalberpengaruh

terhadap

profitabilitas pada PT. Maulana Mitra Media. Hal ini dibuktikan dengan nilai $t$ hitung sebesar 5,728 lebih besar dari t tabel 1,688 dan signifikan sebesar 0,00< dari tingkat yang diisyaratkan yaitu 0,05 .

2.

Utang tidak berpengaruh terhadap profitabilitas pada PT. Maulana Mitra Media. Hal ini dibuktikan dengan nilai $t$ hitung sebesar -3,207 lebih kecil dari t tabel sebesar 1,688 dan signifikan 0,003 < dari tingkat signifikan yang diisyaratkan yaitu 0,05 .

3.

Modal dan utangsecara simultan berpengaruh terhadap profitabilitas pada PT. Maulana Mitra Media. Hal ini dibuktikan dengan F hitung sebesar 17.097 lebih besar dari F tabel sebesar 3,259 dan signifikan sebesar $0,00<$ dari tingkat signifikasi yang diisyaratkan yaitu 0,00

\section{DAFTAR PUSTAKA}

Husein, U. (2011). Metode Penelitian Untuk Skripsi dan Tesis Bisnis Edisi 11. Jakarta: PT Raja Grafindo Persada.

-------. Jensen dan Meckling 1976, Brigham (2006:62),

Latif, A. (2014). Buku Pedoman Penulisan Skripsi Dan Karya Ilmiah Universitas Karimun.

Tanjung Balai Karimun: Universitas Kari,mun.

Purwanto. (2011). Evaluasi Hasil Belajar. Yogyakarta: Pustaka Belajar.

Santoso, S. (2018). Menguasai Statistik Dengan SPSS. Jakarta: PT Elex Media Komputindo.

Sugiyono. (2009). Metode Penelitian Kuantitatif, Kualitatif dan R\&D . Bandung: Alfabeta.

Sugiyono. (2010). Metode Penelitian Pendekatan Kunatitatif, Kualitatif, dan R\&D.

Bandung: Alfabeta.

-------,Kasmir, (2008:40)

Sujarweni, V. W. (2015). Metode Penelitian Bisnis Ekonomi. Yogyakarta: PT Pustaka Baru. Sukardi. (2004). Metode Penelitian Pendidikan. Jakarta: Bumi Putera.

Supranto, N. (2010). Statistik Ekonomi dan Bisnis. Jakarta: Mitra Wacana Media. 
JURNAL CAFETARIA

Vol. 1 No. 1 Januari 2020

Umar, H. (2019). Metode Riset Manajemen Perusahaan. Jakarta: PT Gramedia Pustaka Utama. 